\title{
WEED TECHNOLOOY
}

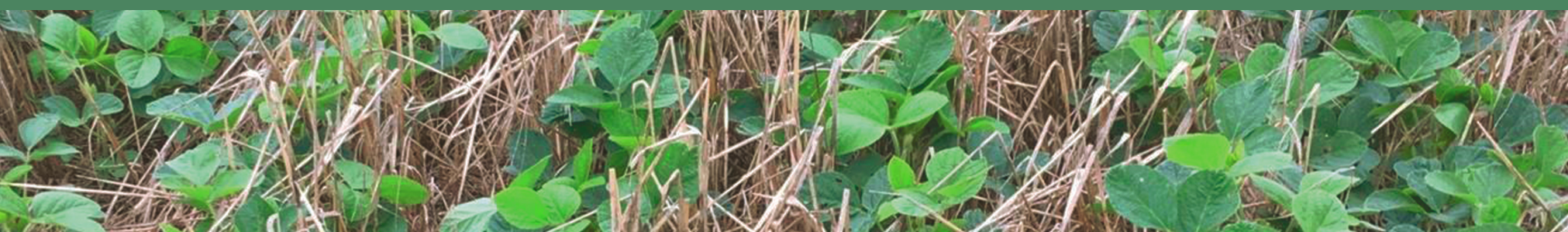
1.

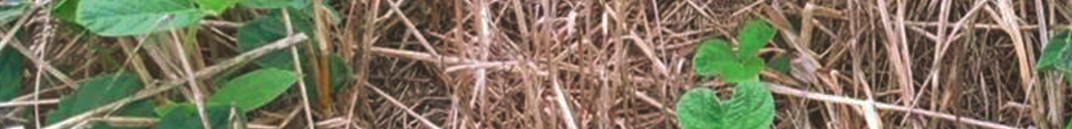

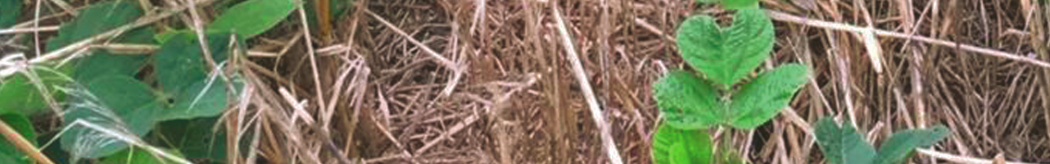

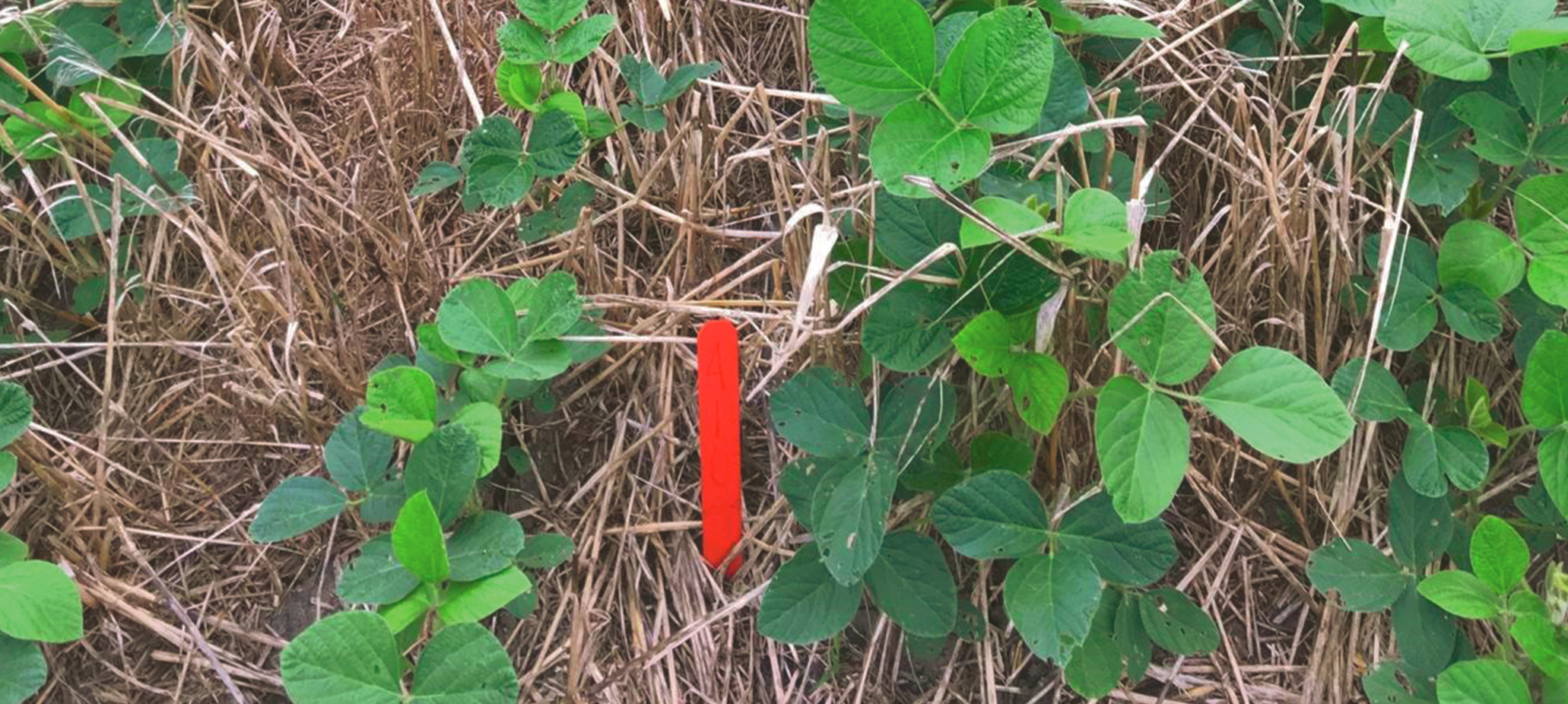
$2+1=$

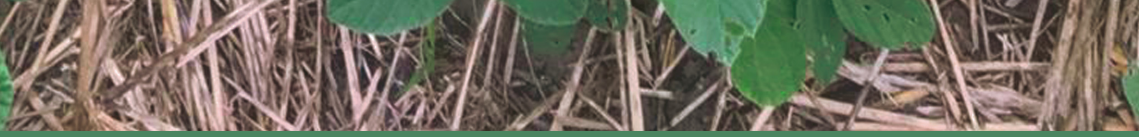




\section{Published six times a year by the Weed Science Society of America}

\section{Jason K. Norsworthy, Editor}

The Weed Science Society of America publishes original research and scholarship in the form of peer-reviewed articles in three international journals. Weed Science is focused on understanding "why" phenomena occur in agricultural crops. As such, it focuses on fundamental research directly related to all aspects of weed science in agricultural systems. Weed Technology focuses on understanding "how" weeds are managed. As such, it is focused on more applied aspects concerning the management of weeds in agricultural systems. Invasive Plant Science and Management is a broad-based journal that focuses not only on fundamental and applied research on invasive plant biology, ecology, management, and restoration of invaded non-crop areas, but also on the many other aspects relevant to invasive species, including educational activities, policy issues, and case study reports. Topics for Weed Technology include all aspects of weed management in agricultural, horticultural, ornamental, forestry, aquatic, turf, recreational, rights-of-ways, and other settings; weed resistance to herbicides; herbicide resistant crops; biological weed control agents; new weed management techniques; impacts of weed competition with crops; vegetation management with plant growth regulators; weed surveys; weed-related grower surveys; education; and extension. Symposia papers and reviews are accepted. Consult the editor for additional information.

\section{Associate Editors (Assignment Year)}

Jason Bond, Stoneville, MS (2010)

Kevin Bradley, Columbia, MO (2012)

Barry Brecke, Jay, FL (2013)

Ian Burke, Pullman, WA (2007)

Peter Dittmar, Gainesville, FL (2016)

Steve Fennimore, Salinas, CA (2004)

Aaron Hager, Urbana, IL (2012)
Brad Hanson, Davis, CA (2013)

Prashant Jha, Huntley, MT (2016)

William Johnson, West Lafayette, IN (2007)

Andrew Kniss, Laramie, WY (2016)

Patrick McCullough, Griffin, GA (2016)

Scott McElroy, Auburn, AL (2012)

Robert Nurse, Guelph, ON (2016)
Darren Robinson, Ridgetown, ON (2008)

Larry Steckel, Jackson, TN (2007)

Daniel Stephenson, Alexandria, LA (2013)

Mark VanGessel, Georgetown, DE (2013)

Michael Walsh, Crawley, Australia (2016)

Cammy Willett, Fayetteville, AR (2017)

\section{Tracy Candelaria, Managing Editor}

\section{Officers of the Weed Science Society of America}

\author{
Janis McFarland, President \\ Scott Senseman, President-Elect \\ Larry Steckel, Vice President \\ Kevin Bradley, Past President
}

Hilary Sandler, Secretary

Rick Boydston, Treasurer

Sarah Ward, Director of Publications

Mark Bernards, Chair, Constitution and Operating Procedures

Weed Technology (ISSN 0890-037X) is published by the Weed Science Society of America, 12011 Tejon Street, Suite 700, Westminster, CO 80234. It is published bimonthly, one volume per year, six issues per year beginning in January.

Membership includes online access to Weed Technology, Weed Science, Invasive Plant Science and Management, and the online WSSA Newsletter. Dues should be sent to WSSA, 12011 Tejon Street, Suite 700, Westminster, CO 80234 no later than December 1 of each year. Membership in the society is on a calendar-year basis only.

New subscriptions and renewals begin with the first issue of the current volume. Please visit the Weed Technology subscription page at https://www.cambridge.org/core/journals/weed-technology/subscribe; Email: subscriptions_newyork@cambridge.org in USA, journals@cambridge.org outside USA.

Weed Technology publishes six times a year in January, March, May, July, September, and November. Annual institutional electronic subscription rates: US \$351.00; UK £254.00.

Please use Editorial Manager to access manuscript submissions (http://www.editorialmanager.com/wt). Authors are asked to pay $\$ 85$ for the first page and $\$ 65$ per page thereafter as a portion of the cost of publication, plus an additional processing charge of \$55 per manuscript if none of the authors are WSSA members. The Editor can make exceptions in advance when justified.

The Weed Science Society of America fully subscribes to the belief that progress in science depends upon the sharing of ideas, information, and materials among qualified investigators. Authors of papers published in Weed Technology are therefore encouraged, whenever practicable and when state and federal laws permit, to share genotypically unique propagative materials they might possess with other workers in that area who request such materials for the purpose of scientific research.

Weed Technology published by the Weed Science Society of America.

Copyright 2017 by the Weed Science Society of America.

All rights reserved. Reproduction in part or whole prohibited.

\section{Cover}

The cover photograph is from Loux et al. (Pp 487-495). Cereal cover crops are an effective option for suppressing emergence of Amaranthus species and other weeds in soybean. Photo provided by Mark Loux. 


\section{WEED TECHNOLOGY}

VOLUME 31

JULY-AUGUST 2017

NUMBER 4

\section{- WEED MANAGEMENT-MAJOR CROPS}

Influence of Cover Crops on Management of Amaranthus Species in Glyphosate- and Glufosinate-Resistant Soybean. Mark M. Loux, Anthony F. Dobbels, Kevin W. Bradley, William G. Johnson, Bryan G. Young, Douglas J. Spaunhorst, Jason K. Norsworthy, Matheus Palhano, and Lawrence E. Steckel . . . . . . . . . . . . . . . . . . . 487 Weed Management Programs with Pyroxasulfone in Field Corn (Zea mays). Daniel O. Stephenson IV, Jason A. Bond, James L. Griffin, Randall L. Landry, Brandi C. Woolam, H. Matthew Edwards, and John M. Hardwick . . . . . . . . . . 496 Influence of Various Cover Crop Species on Winter and Summer Annual Weed Emergence in Soybean. Cody D. Cornelius and Kevin W. Bradley . . . . . . . . . . . . . . . . . . . . . . . . . . . 503 Herbicide Programs for the Termination of Various Cover Crop Species. Cody D. Cornelius and Kevin W. Bradley . . . . . 514 Utilization of Chlorophyll Fluorescence Imaging Technology to Detect Plant Injury by Herbicides in Sugar Beet and Soybean. Jonas F. Weber, Christoph Kunz, Gerassimos G. Peteinatos, Hans-Joachim Santel, and Roland Gerhards. . . . . . . . . . . . . . . . . . . . . . . . . . . . . . . . . . 523 High Planting Rates Improve Weed Suppression, Yield, and Profitability in Organically-Managed, No-till-Planted Soybean. Jeffrey A. Liebert and Matthew R. Ryan . . . . . . . . . . . . . . . . . . . . . . . . . 536 Effect of Time of Day of Application of 2,4-D, Dicamba, Glufosinate, Paraquat, and Saflufenacil on Horseweed (Conyza canadensis) Control. Garret B. Montgomery, Joyce A. Treadway, Julie L. Reeves, and Lawrence E. Steckel. . . . 550

\section{- WEED MANAGEMENT-OTHER CROPS/AREAS}

Using Reduced Tillage and Cover Crop Residue to Manage Weeds in Organic Vegetable Production. Guihua Chen,

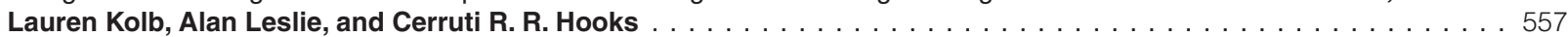

Preemergence and Postemergence Control of Artilleryweed (Pilea microphylla) in Container Nurseries and Landscapes. Debalina Saha, S. Christopher Marble, Cody Stewart, and Annette Chandler . . . . . . . . . . . . . . . . . . 574 Postemergence Control and Glyphosate Tolerance of Doveweed (Murdannia nudiflora). Jeffrey L. Atkinson, Lambert B. McCarty, Brian A. Powell, Scott McElroy, Fred Yelverton, and Alan G. Estes . . . . . . . . . . . . . . 582 Sesame Tolerance to Preplant Applications of 2,4-D and Dicamba. Benjamin P. Sperry, Jason A. Ferrell, Ramon G. Leon, Diane L. Rowland, Michael J. Mulvaney, and Jose Luiz C. S. Dias . . . . . . . . . . . . . . . . . . . . . . . 590 Repeated Applications of Mesotrione and Napropamide on New Cranberry Plantings. Hilary A. Sandler . . . . . . . . . . 599 A Diagnostic Assay to Detect Herbicide Resistance in Annual Bluegrass (Poa annua). James T. Brosnan, Jose J. Vargas, Eric H. Reasor, Roberto Viggiani, Gregory K. Breeden, and John M. Zobel . . . . . . . . . . . . . . . . . . . . . 609

\section{- WEED BIOLOGY AND COMPETITION}

Seed Retention of Palmer amaranth (Amaranthus palmeri) and Barnyardgrass (Echinochloa crus-galli) in Soybean. Lauren M. Schwartz-Lazaro, Jeremy K. Green, and Jason K. Norsworthy . . . . . . . . . . . . . . . . . . . . 617 Influence of Tillage on Common Ragweed (Ambrosia artemisiifolia) Emergence Pattern in Nebraska. Ethann R. Barnes, Rodrigo Werle, Lowell D. Sandell, John L. Lindquist, Stevan Z. Knezevic, Peter H. Sikkema, and Amit J. Jhala 623 